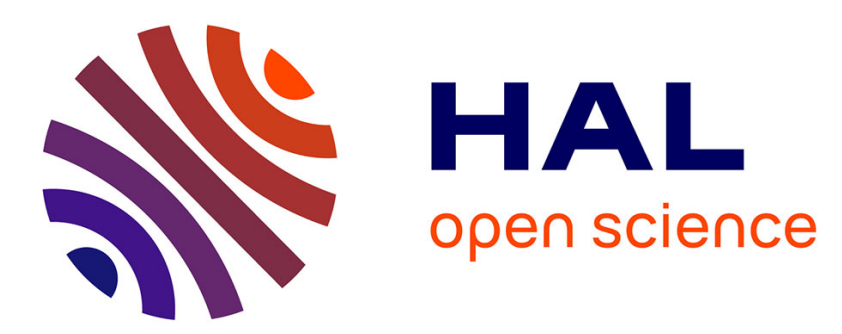

\title{
Temporal and Spatial Variations of Freshwater Reservoir Ages in the Loire River Watershed
}

\author{
C Coularis, N. Tisnérat-Laborde, L Pastor, F. Siclet, M. Fontugne
}

\section{To cite this version:}

C Coularis, N. Tisnérat-Laborde, L Pastor, F. Siclet, M. Fontugne. Temporal and Spatial Variations of Freshwater Reservoir Ages in the Loire River Watershed. Radiocarbon, 2016, 58 (3), pp.549-563. 10.1017/RDC.2016.36 . hal-02468256

\section{HAL Id: hal-02468256 https://hal.science/hal-02468256}

Submitted on 15 Jun 2021

HAL is a multi-disciplinary open access archive for the deposit and dissemination of scientific research documents, whether they are published or not. The documents may come from teaching and research institutions in France or abroad, or from public or private research centers.
L'archive ouverte pluridisciplinaire HAL, est destinée au dépôt et à la diffusion de documents scientifiques de niveau recherche, publiés ou non, émanant des établissements d'enseignement et de recherche français ou étrangers, des laboratoires publics ou privés. 


\title{
TEMPORAL AND SPATIAL VARIATIONS OF FRESHWATER RESERVOIR AGES IN THE LOIRE RIVER WATERSHED
}

\author{
C Coularis $^{1,2} \cdot \mathrm{N}$ Tisnérat-Laborde ${ }^{2 *} \cdot$ L Pastor $^{1} \cdot$ F Siclet $^{1} \cdot$ M Fontugne $^{2}$ \\ ${ }^{1}$ EDF R\&D, Laboratoire National d'Hydraulique et Environnement, 6 quai Wattier, F-78401 Chatou, France. \\ ${ }^{2}$ Laboratoire des Sciences du Climat et de l'Environnement/IPSL, CEA-CNRS-UVSQ, Université Paris-Saclay, \\ Avenue de la Terrasse, Bâtiment 12, F-91190 Gif-sur-Yvette, France.
}

\begin{abstract}
In order to map the freshwater reservoir effect (FRE) variability of the Loire River and its tributaries, spatial and temporal carbon isotope $\left({ }^{13} \mathrm{C}\right.$ and $\left.{ }^{14} \mathrm{C}\right)$ analyses of the dissolved inorganic carbon (DIC) were conducted. Sites were selected to represent the diversity of geological settings, soil type, and land use. Results show a large spatial varia-bility of ${ }^{14} \mathrm{C}$ FRE ranging between 135 and $2251 \pm 30 \mathrm{yr}$, objectively correlated to DIC contents and alkalinity. Deeper investigations of the relationship between ${ }^{14} \mathrm{C}$ activity of DIC and environmental variables show that the geological substrate is the dominant factor in the ${ }^{14} \mathrm{C}$ reservoir effect, and far more influential than the river flow discharge.
\end{abstract}

KEYWORDS: freshwater reservoir effect, Loire River, dissolved inorganic carbon, ${ }^{13} \mathrm{C},{ }^{14} \mathrm{C}$.

\section{INTRODUCTION}

The radiocarbon freshwater reservoir effect (FRE) is the difference between the age of the freshwater carbon reservoirs and the age of atmospheric or terrestrial carbon reservoirs (Ascough et al. 2010). The FRE was first described in 1949 by J Iversen in a private commu-nication (Oana and Deevey 1960). Aquatic plants were the first samples used to measure the FRE, in 1951 by Godwin (Oana and Deevey 1960) and in 1954 by Deevey et al. (1954). Later, FRE was mainly studied in aquatic plants and animals (Broecker and Walton 1959). In the last decade, under the leadership of archaeologists, scientists started to study the FRE in order to apply corrections on ${ }^{14} \mathrm{C}$ dates measured in prehistoric sites. This effect leads to aging of the ${ }^{14} \mathrm{C}$ dates of bone collagen of freshwater fish consumers but is also recorded in nonhuman materials (e.g. ceramic or pottery food crusts, wild or domestic animal remains, terrestrial/aquatic shells, sediments) (Cook et al. 2001; Bonsall et al. 2004; Shishlina et al. 2007; Boudin et al. 2009; Van Strydonck et al. 2009; Higham et al. 2010; Hollund et al. 2010; Olsen et al. 2010; Philippsen et al. 2010; Keaveney and Reimer 2012; Hart et al. 2013).

Previous studies have shown that the FRE varies between a few and several thousand years. For instance, the FRE is estimated between 400 and $5000{ }^{14} \mathrm{C}$ yr in Lake Mývatn (Iceland) (Ascough et al. 2010) or several tens of thousands of years in Mammoth Mountain waters (California, USA) (Sorey et al. 1998), attributed largely to geothermal mechanisms. An FRE of $18,000{ }^{14} \mathrm{C}$ yr was also reported in the Dry Valleys of Antarctica and attributed to an input of ancient glacial meltwater (Hall and Henderson 2001), and in the waters of Waddi Akarit (Tunisia) fed by Saharan fossil water tables (Fontes and Gasse 1991). The FRE is highly variable within a lake or a river and very difficult to estimate because of its multiple origins (Fontugne et al. 2009; Ascough et al . 2010; Philippsen et al. 2010; Philippsen 2012, 2013; Philippsen and Heinemeier 2013).

The FRE results from complex processes involved in dissolved inorganic carbon (DIC) cycling in river systems. These processes involve mainly the chemical weathering of geological ${ }^{14} \mathrm{C}$-free carbonates and silicate, leading to the so-called hardwater effect (Deevey et al. 1954). The decom-position of other rocks such as volcanic glasses and geothermal $\mathrm{CO}_{2}$ can also cause significant aging in DIC in groundwaters (Sveinbjörnsdóttir et al. 1995) and in mineral water sources (Boineau and Maisonneuve 1971; Sorey et al. 1998). Atmospheric $\mathrm{CO}_{2}$ also exchanges with DIC, reducing the

*Corresponding author. Email: Nadine.Tisnerat@ lsce.ipsl.fr. 
FRE in well-ventilated rivers. Finally, synthesis and decomposition processes of organic matter in rivers contribute to FRE variations since organic carbon records partly the seasonal variability of the ${ }^{14} \mathrm{C}$ concentration in DIC (Buhl et al. 1991; Aucour et al. 1999). A better understanding of these variations will lead to better description of the FRE evolution.

In this study, we investigated the spatial and temporal variability of the FRE in the largest French river, the Loire, and its main tributaries in 2004, 2005, 2013, and 2014. Through measurements of

${ }^{14} \mathrm{C}$ ages and DIC $\delta^{13} \mathrm{C}$ combined with physico-chemical parameters, we tried to assess the main factors controlling these ages on a spatial and temporal basis.

\section{STUDY AREA}

\section{Study Site}

The Loire is the largest French river with a length of $1010 \mathrm{~km}$ and major inputs (carbon, nutrients, and flow rate) to the northeastern Atlantic Ocean with a water discharge of $26 \mathrm{~km}^{3} / \mathrm{yr}$

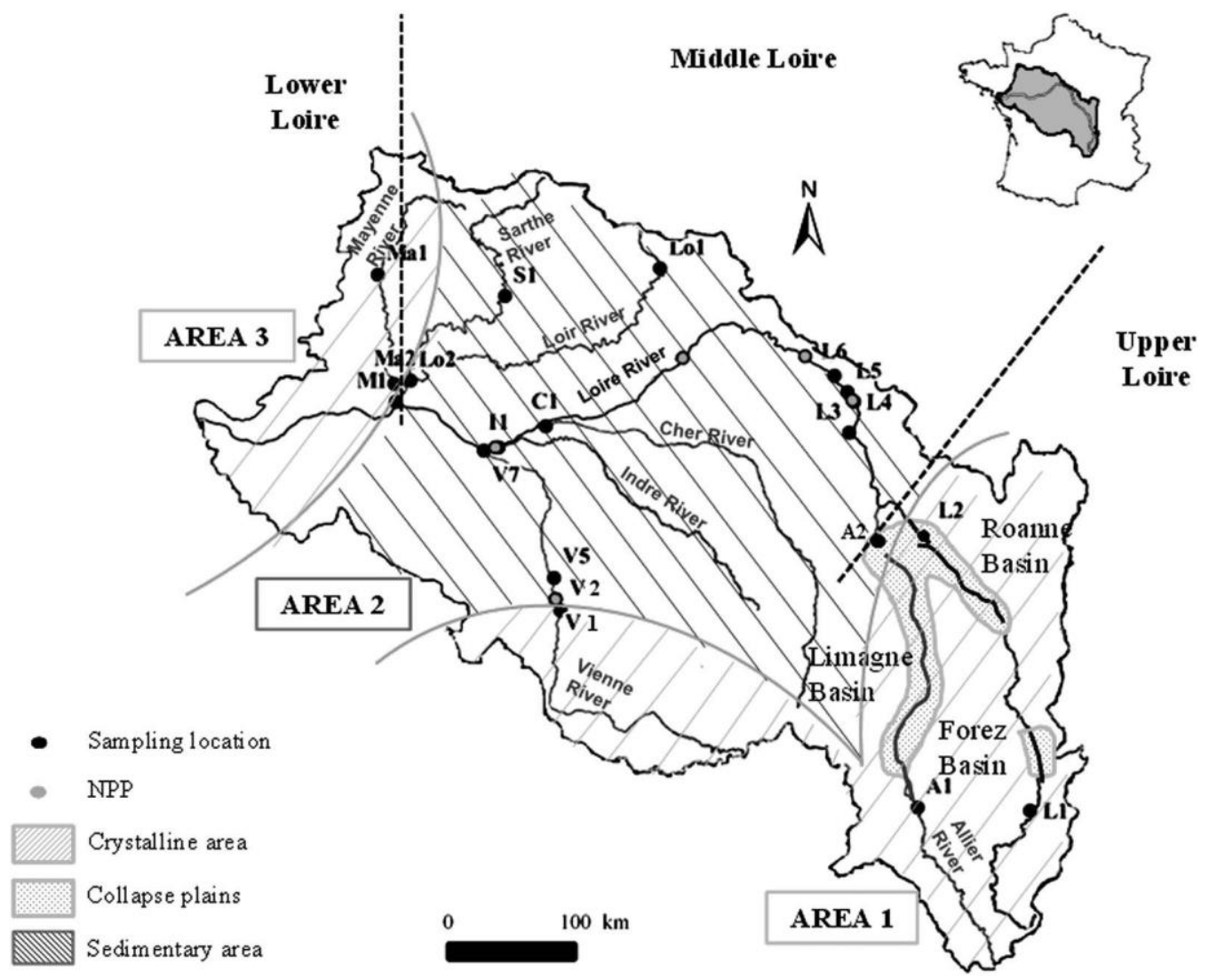

Figure 1 Loire River Basin. The upper part of the Loire River is upstream of the confluence of the Allier and Vienne rivers. The middle part of the Loire River is between the confluence of the Allier and Loire rivers and the confluence of the Maine and Loire rivers. The lower part of the Loire River is downstream the confluence of the Maine and Loire rivers. Sampling sites and nuclear power plants (NPP) are represented by black and red points, respectively (online version of the article). Three areas are identified: Area 1 and 3 are crystalline regions (striped orange zone) and Area 2 is a region with carbonaceous sediments (striped blue zone). The dotted region represents the carbonated collapse plain between the Limagne Plain, the Roanne Basin, and the Forez Basin. 
(Figueres et al. 1985). The Loire River system drains a $117,800 \mathrm{~km}^{2}$ basin, which represents $20 \%$ of the surface area of France (Abonyi et al. 2012; Figure 1). From its source in the Southern Massif Central, the Loire flows through agricultural regions to the Atlantic Ocean (Minaudo et al. 2013). The left bank tributaries studied here are the Allier (A), Cher (C), Indre (I), and Vienne (V) rivers. The Maine (M) River, formed by the confluence of the Mayenne (Ma), Sarthe (S), and Loir (Lo) rivers, is the only tributary studied on the right bank. These tributaries were chosen based on their differences in geological settings, land use, and flow rate.

The Loire Basin drains three areas that are significantly different in geological substrate (Figure 1; Mansy et al. 2008). In Area 1, to the west, the upper segment of the Vienne River drains the Limousin granite formation and goes towards $46^{\circ} 30^{\prime} \mathrm{N}$, in the Jurassic limestone of the Paris Basin. South of $45^{\circ} 30^{\prime} \mathrm{N}$, the Upper Loire and Allier rivers drain the Hercynian crystalline formation of the Massif Central, which has been characterized since the Miocene period by significant volcanic activity.

Area 2 consists of the Jurassic to Miocene sedimentary formation of the Paris Basin. These sediments are mostly limestone and constitute the substrate of the Loir, Sarthe, lower Vienne, Indre, Cher, and middle Loire riverbeds. The upstream parts of the Loire and Allier rivers enter the Forez and Limagne collapse plains, respectively. These faulted basins covered by eolian Quaternary deposits (loess) are well known for their hydrothermal activities and numerous mineral springs.

Area 3 is the eastern edge of the Massif Armoricain Paleozoic formation, which is composed of granitic and metamorphic (gneiss or schist) rocks. Nevertheless, some fractures may be filled by carbonate deposits as is the case for the Changé formation in the upper course of the Mayenne River (Aertgeerts et al. 2011a).

The Loire River and its five tributaries are situated in the central part of France where the climate is temperate. The annual mean temperature in the Loire Basin is $11^{\circ} \mathrm{C}$. The rivers are supplied either by groundwater and/or precipitation, and melting snows during the spring only in the upper course of the Allier and Loire rivers. The altitude along the Loire River is from $1408 \mathrm{~m}$ near the source to $0 \mathrm{~m}$ above sea level (asl) at the estuary (Grosbois 1998).

\section{Sampling Sites}

In this study, 20 sampling sites were selected in the Loire Basin (Table 1, Figure 1). They cover a wide range of geological substrates and agricultural practices. Six sampling sites are situated in the headwater and in the beginning of the middle part of the Loire River from Aurec-sur-Loire (L1) to Briare (L6). Several nuclear power plants are located on the Loire and Vienne rivers, and can potentially release liquids containing ${ }^{14} \mathrm{C}$ in DIC form and tritium, mainly (Siclet et al. 2002). Tritium is commonly used as a tracer for these releases and was measured in this study to identify a potential release. These values were indeed closely related to the periods of releases communicated by the energy industry. Two sites presented in this study (L5 and L6) were located downstream of a nuclear power plant. The samples used in this study were strictly selected during nonrelease periods. In previous studies, no memory effect was observed after a release (Fontugne et al. 2007).

A few sites are located on noncarbonaceous bedrock. In Area 1, two sites (L1 and A1) are locate d in the crystalline formation. Lussac (V1) is located at the boundary between Area 1 and 2. At this location, the Vienne River flows out from the Limousin crystalline formation and does not reach the Lias and Jurassic limestone formations situated in the northeastern part of 
Table 1 Sampling sites location on the Loire River Basin. Kilometric Point 0 is situated at Saint Nazaire near the estuary $\left(47^{\circ} 16^{\prime} 04^{\prime \prime} \mathrm{N} ; 2^{\circ} 11^{\prime} 08^{\prime \prime} \mathrm{W}\right)$.

\begin{tabular}{llllll}
\hline Rivers & $\mathrm{N}^{\circ}$ & Location & Latitude N & Longitude & Kilometric points (rkms)* \\
\hline Loire & L1 & Aurec-sur-Loire & $45^{\circ} 22^{\prime} 09^{\prime \prime}$ & $4^{\circ} 11^{\prime} 39^{\prime \prime} \mathrm{E}$ & 847.0 \\
& L2 & Decize & $46^{\circ} 49^{\prime} 40^{\prime \prime}$ & $3^{\circ} 27^{\prime} 27^{\prime \prime} \mathrm{E}$ & 553.4 \\
& L3 & Saint Satur & $47^{\circ} 20^{\prime} 19^{\prime \prime}$ & $2^{\circ} 51^{\prime} 33^{\prime \prime} \mathrm{E}$ & 497.2 \\
& L4 & Belleville-sur-Loire & $47^{\circ} 30^{\prime} 16^{\prime \prime}$ & $2^{\circ} 53^{\prime} 13^{\prime \prime} \mathrm{E}$ & 477.1 \\
& L5 & Bonny-sur-Loire & $47^{\circ} 33^{\prime} 01^{\prime \prime}$ & $2^{\circ} 50^{\prime} 06^{\prime \prime} \mathrm{E}$ & 474.1 \\
& L6 & Briare & $47^{\circ} 37^{\prime} 55^{\prime \prime}$ & $2^{\circ} 44^{\prime} 14^{\prime \prime} \mathrm{E}$ & 447.4 \\
Allier & A1 & Auzon & $45^{\circ} 23^{\prime} 08^{\prime \prime}$ & $3^{\circ} 21^{\prime} 23^{\prime \prime} \mathrm{E}$ & Confluence with Loire River \\
& A2 & Le Veurdre & $46^{\circ} 45^{\prime} 28^{\prime \prime}$ & $3^{\circ} 2^{\prime} 56^{\prime \prime} \mathrm{E}$ & \\
Cher & C1 & Savonnières & $47^{\circ} 20^{\prime} 54^{\prime \prime}$ & $0^{\circ} 32^{\prime} 34^{\prime \prime} \mathrm{E}$ & 241.8 \\
Indre & I1 & Le Neman & $47^{\circ} 13^{\prime} 55^{\prime \prime}$ & $0^{\circ} 11^{\prime} 50^{\prime \prime} \mathrm{E}$ & 216.6 \\
Vienne & V1 & Lussac-les-Châteaux & $46^{\circ} 24^{\prime} 16^{\prime \prime}$ & $0^{\circ} 42^{\prime} 07^{\prime \prime} \mathrm{E}$ & 206.0 \\
& V2 & Civaux upstream & $46^{\circ} 27^{\prime} 31^{\prime \prime}$ & $0^{\circ} 39^{\prime} 49^{\prime \prime} \mathrm{E}$ & \\
& V5 & Chauvigny & $46^{\circ} 34^{\prime} 10^{\prime \prime}$ & $0^{\circ} 38^{\prime} 29^{\prime \prime} \mathrm{E}$ & \\
Maine & M1 & Candes-Saint-Martin & $47^{\circ} 12^{\prime} 36^{\prime \prime}$ & $0^{\circ} 04^{\prime} 45^{\prime \prime} \mathrm{E}$ & \\
Mayenne & Ma1 & Bouchemaine & $47^{\circ} 26^{\prime} 40^{\prime \prime}$ & $0^{\circ} 35^{\prime} 47^{\prime \prime} \mathrm{W}$ & 134.0 \\
& Ma2 & Montreuil-Juigné & $48^{\circ} 05^{\prime} 57^{\prime \prime}$ & $0^{\circ} 47^{\prime} 06^{\prime \prime} \mathrm{W}$ & - \\
Sarthe & S1 & Le Mans & $48^{\circ} 02^{\prime \prime} 47^{\prime \prime}$ & $0^{\circ} 36^{\prime} 50^{\prime \prime} \mathrm{W}$ & \\
Loir & Lo1 & Bonneval $56^{\prime \prime} \mathrm{E}$ & - \\
& Lo2 & Briollay & $48^{\circ} 10^{\prime} 44^{\prime \prime}$ & $1^{\circ} 23^{\prime} 22^{\prime \prime} \mathrm{E}$ & - \\
& & $47^{\circ} 33^{\prime 2} 29^{\prime \prime}$ & $0^{\circ} 30^{\prime} 03^{\prime \prime} \mathrm{W}$ & \\
\hline
\end{tabular}

the plateau. Similarly, Decize (L2) is located at the junction of a crystalline and a sedimentary formation and Loire River waters come out of a sandy clay zone north of the Roanne Basin before running on Jurassic limestones. All the other sites are in the carbonate sedimentary context of Area 2, except for sites Ma1 and Ma2, which are partially in the metamorphic context (shale) of Area 3 (Aertgeerts et al. 2011a). Sites L2 (Area 1) and A2 (Area 2) are in the collapse basins. Site $\mathrm{C} 1$ is on the Cher River at Savonnières near the Mesozoic carbonate petrified caves (Couderc 1968). Site M1 at Bouchemaine on the Maine River reflects the mixing of its different tributaries: the Mayenne (Ma1, Ma2), Sarthe (S1, Aertgeerts et al. 2011b), and Loir (Lo1, Lo2) rivers. Four sampling sites are distributed on the Vienne River: V1 at the limit of the granitic area and V2, V5, V7 in a carbonate complex area, downstream from a nuclear power plant (SAGE 2006).

For this study, four sampling campaigns were conducted in April, July, and October 2013 and March 2014. According to hydrological and meteorological conditions, the July and Octo ber 2013 sampling represented summer conditions while April 2013 and March 2014 represented winter/early spring conditions. All sites were sampled during these campaigns, except V2 (upstream Civaux) that was sampled only in July and October 2013 and upstream sites of the Loire and tributaries (L1, A1, Ma1, S1, and Lo1) that were sampled in March 2014. We also used unpublished data from three other campaigns conducted in September 2004, May 2005, and November 2005 in which the sampling sites were located in the middle Loire River and the samples were collected on the riverbank (Fontugne et al. 2007; Marang et al. 2011). 


\section{METHODS}

In this study, surface water samples were collected from bridges in the main water flow on the Loire River and its tributaries. They were taken from 0-0.5 m depth using a bucket (Garnier et al . 2001; Sato et al. 2006).

For chlorophyll-a (hereafter chl-a) analysis, water was immediately filtered using a precombusted $\left(450^{\circ} \mathrm{C}\right)$ Whatman glass fiber filter $(\mathrm{GF} / \mathrm{F}, 0.7-\mu \mathrm{m}$ pore diameter $)$. The filter was stored at $-80^{\circ} \mathrm{C}$ in aluminum foil to prevent light degradation until analysis, around 1 week later. Chl-a was then analyzed by spectrofluorimetry according to Neveux and Lantoine (1993) at the Station Marine d'Arcachon (University of Bordeaux I).

For alkalinity analysis, water was immediately filtered using a precombusted $\left(450^{\circ} \mathrm{C}\right), 47-\mathrm{mm}-$ diameter Whatman quartz fiber filter (QM/A, 2.2- $\mu \mathrm{m}$ pore diameter) and stored at $4{ }^{\circ} \mathrm{C}$ until analysis. The analysis was performed within 1 week by potentiometric titration with $\mathrm{HCl} 0.01 \mathrm{~N}$, using the Gran method. We expressed the results in meq/L assuming that alkalinity is mainly represented by bicarbonates and carbonates. The precision was around $5 \%$.

For the DIC concentration and $\delta^{13} \mathrm{C}$ and ${ }^{14} \mathrm{C}$ analysis, water samples were transferred to precleaned (TBF4, $10 \% \mathrm{HCl}$, pure water) and combusted $\left(450^{\circ} \mathrm{C}\right.$, overnight $) 250$-mL bor-osilicate ground neck bottles and poisoned with $1 \mathrm{~mL}$ of a saturated solution of mercury (II) chloride (Leboucher et al. 1999). The borosilicate bottles were then sealed with greased ground glass stoppers (Apiezon $\mathrm{H}$ ).

In the laboratory, 80 to $200 \mathrm{~mL}$ of water sample and $2 \mathrm{~mL}$ of $85 \% \mathrm{H}_{3} \mathrm{PO}_{4}$ were introduced in a glass reactor in a vacuum line for the extraction of DIC as free $\mathrm{CO}_{2}$ (Leboucher et al. 1999). The sample was purged using ultra-high-purity (6.0) helium gas. The $\mathrm{CO}_{2}$ was dried by passing through two water traps (ethanol/dry ice) before being trapped in a liquid nitrogen trap. Then, the $\mathrm{CO}_{2}$ was manometrically quantified in a calibrated volume and separated in 2 aliquots: one for ${ }^{14} \mathrm{C}$ measurement and the other for stable carbon isotope measurement. $\delta^{13} \mathrm{C}$ values were determined at LSCE using a dual-inlet VG-Optima isotopic ratio mass spectrometer (typical precision below $0.08 \%$ ). The DIC concentration was calculated from the amount of carbon extracted and the volume of extracted water and expressed in $\mathrm{mgC} / \mathrm{L}$ with a precision of $1 \%$.

${ }^{14} \mathrm{C}$ measurements were performed with the Artemis accelerator mass spectrometry (AMS) facility at the Laboratoire de Mesure du Carbone 14 in Saclay (France). Prior to measurement, the evolved $\mathrm{CO}_{2}$ was converted to graphite (Cottereau et al. 2007). The ${ }^{14} \mathrm{C}$ activities are reported in fraction modern $\left(\mathrm{F}^{14} \mathrm{C}\right.$ ) and ${ }^{14} \mathrm{C}$ age (Stuiver and Polach 1977; Reimer et al. 2004). All ${ }^{14} \mathrm{C}$ values were corrected from the delay between sampling and measurement years and background subtraction. The total uncertainty for the ${ }^{14} \mathrm{C}$ activity values was $\pm 0.003 \mathrm{~F}^{14} \mathrm{C}$, corresponding to an age of $\pm 30 \mathrm{yr}$. According to the definition, the FRE was calculated as follows:

$$
\mathrm{FRE}=8033 \ln \mathrm{F}^{14} \mathrm{CS}_{\mathrm{S}}=\mathrm{F}^{14} \mathrm{C}_{\mathrm{A}}
$$

where $\mathrm{F}^{14} \mathrm{CS}_{\mathrm{S}}$ and $\mathrm{F}^{14} \mathrm{C}_{\mathrm{A}}$ are the sample modern fraction and the atmospheric sample modern fraction, respectively (Keaveney and Reimer 2012). We used the conventional values of Levin et al. (2013) and unpublished data (Samuel Hammer and Ingeborg Levin, personal commu-nication, $2015)$ for the atmospheric sample age. We calculated the mean annual value of the atmosphere activity in $2004,2005,2013$, and 2014 and obtained $\mathrm{F}^{14} \mathrm{C}$ values of $1.0674,1.0644,1.0284$, and 1.0258 , respectively. 


\section{River Discharge}

River discharge data of the Loire River were taken from the national BanqueHydro database (http://www.hydro.eaufrance.fr). Data collected between 2004 and 2014 were used to estimate the mean discharge at each sampling site for this period. We then calculated the mean discharge percentage according to the following equation to evaluate the streamflow river states in flood or low water:

$$
\% \text { of mean discharge }=\text { Mean discharge } 100
$$

\section{RESULTS AND DISCUSSION}

River discharge, chlorophyll-a concentration, alkalinity, DIC concentration, DIC $\delta^{13} \mathrm{C},{ }^{14} \mathrm{C}$ activity, and reservoir age are reported in Table 2. Unpublished values obtained during the 2004 and 2005 LORA experiments (Fontugne et al. 2007) are also reported in italics in Table 2. Some reservoir age values are missing because sampling sites were under the influence of a nuclear power plant release or because the measurement failed.

\section{Chlorophyll-a}

Chl-a concentrations showed large variations ranging between 0.4 and $152.8 \mu \mathrm{g} / \mathrm{L}$ in the Loire River Basin. The highest concentrations $(>44 \mu \mathrm{g} / \mathrm{L})$ were recorded in the Maine Basin $(\mathrm{M} 1$ and tributaries) in the early spring (March 2013 and April 2014) and are likely associated with spring phytoplankton blooms when the optimal sunlight conditions trigger an intense photo-synthetic activity. This high chl-a concentration can also be explained by the water composition of the Maine River's tributaries, which drain large areas of cereal crops involving fertilizers that may promote an even higher rate of aquatic photosynthesis. Low values (below $10 \mu \mathrm{g} / \mathrm{L}$ ) were observed in wine-growing zones and cattle-breeding areas, in the upper and the beginning of the middle Loire as well as in the Allier, Indre, Cher, and Vienne tributaries. This low chl-a concentration is consistent with previous studies (Aleya et al. 1994; Jugnia et al. 2004) that indicated eutrophic water in headwater due to the nature of the phytoplankton assemblage (lakelike) that does not survive in the turbulent and quite turbid river (Abonyi et al. 2012,2014). A few high values between 22.0 and $37.9 \mu \mathrm{g} / \mathrm{L}$ were observed in these rivers occurring typically at the beginning of spring and summer. In the Loire River, higher chl-a concentration mean values (16.8 $\mu \mathrm{g} / \mathrm{L})$ were observed in spring and summer 2004-2005 than during the four campaigns in 2013$2014(10.4 \mu \mathrm{g} / \mathrm{L})$. These results are consistent with the study by Minaudo et al. (2015) that showed the decline of chl-a concentration over the last decade mainly due to the continuous decline of phosphate concentrations.

\section{Alkalinity and DIC Concentration}

Alkalinity and DIC concentration values varied from 0.6 to $7.7 \mathrm{meq} / \mathrm{L}$ and from 2.0 to 56.6 $\mathrm{mgC} / \mathrm{L}$, respectively, and were highly correlated $(\mathrm{r}=0.92 ; \mathrm{n}=49 ; \mathrm{p}<0.05)$. The alkalinity was higher in sedimentary limestone areas than in crystalline areas, suggesting that chemical weathering of carbonates and silicates is the main process influencing alkalinity in the Loire Basin. This seems to indicate the low contribution of atmospheric $\mathrm{CO}_{2}$ and river exchange. The highest DIC concentrations measured in the Cher and Indre rivers are not surprising due to the presence of petrifying springs in the basin. High concentrations of DIC were also observed in the Loir. This area is mostly composed of arable land. An extensive drainage in the river catchment can be created by intensive agricultural practices, which could imply a significant increase in the export of DIC as observed by Barnes and Raymond (2009). 
Table 2 River discharge (data from www.hydro.eaufrance.fr), chlorophyll-a concentration, alkalinity, DIC concentration, DIC $\delta^{13} \mathrm{C}$, ${ }^{14} \mathrm{C}$ activity and reservoir age for the 20 sampling sites in the Loire River Basin. Sampling year and month are specified after the location name. Unpublished values obtained during the 2004 and 2005 LORA experiments (Fontugne et al. 2007) are reported in italic (nd = not determined).

\begin{tabular}{|c|c|c|c|c|c|c|c|c|c|c|c|c|c|c|c|}
\hline \multirow{2}{*}{$\frac{\text { Rivers }}{\text { Loire }}$} & \multirow{2}{*}{$\frac{\mathrm{Nr}}{\mathrm{L} 1}$} & \multirow{2}{*}{$\begin{array}{l}\text { Sampling location } \\
\text { (yy/mm) } \\
\text { Aurec-sur Loire } \\
14 / 03\end{array}$} & \multirow{2}{*}{$\begin{array}{l}\text { Lab nr } \\
\text { SacA- } \\
38566\end{array}$} & \multirow{2}{*}{$\begin{array}{l}\text { Lab nr } \\
\text { GifA- } \\
14089\end{array}$} & \multirow{2}{*}{$\begin{array}{c}\begin{array}{l}\text { Discharge* } \\
3 \\
\left(\mathrm{~m}^{3} / \mathrm{s}\right)\end{array} \\
26.0\end{array}$} & \multirow{2}{*}{$\begin{array}{l}\begin{array}{l}\text { Percentage of } \\
\text { mean discharge }\end{array} \\
80 \%\end{array}$} & \multicolumn{2}{|c|}{$\begin{array}{l}\text { Chl-a } \\
(\mu \mathrm{g} / \mathrm{L})\end{array}$} & \multirow{2}{*}{$\begin{array}{l}\begin{array}{l}\text { Alkalinity } \\
(\mathrm{meq} / \mathrm{L})\end{array} \\
1.13 \pm 0.06\end{array}$} & \multirow{2}{*}{$\begin{array}{l}\begin{array}{l}\text { DIC } \\
(\mathrm{mgC} / \mathrm{L})\end{array} \\
5.9 \pm 0.1\end{array}$} & \multirow{2}{*}{$\begin{array}{l}\delta^{13} \mathrm{C}-\mathrm{DIC} \\
(\%) \\
-7.88 \pm 0.08\end{array}$} & \multicolumn{2}{|c|}{$\begin{array}{l}\mathrm{F}^{\mathrm{I}} \mathrm{C}-\mathrm{DIC} * \\
100\end{array}$} & \multicolumn{2}{|c|}{$\begin{array}{l}\text { Reservoir } \\
\text { age }\left({ }^{14} \mathrm{C} \text { yr }\right)\end{array}$} \\
\hline & & & & & & & 10.8 & \pm 1.0 & & & & 99.2 & \pm 0.2 & 273 & \pm 30 \\
\hline & $\mathrm{L} 2$ & Decize 13/04 & 33201 & 13112 & 204.0 & $121 \%$ & 22.0 & \pm 2.0 & $1.48 \pm 0.07$ & $7.1 \pm 0.1$ & $-9.48 \pm 0.08$ & 95.6 & \pm 0.3 & 586 & \pm 30 \\
\hline & L2 & Decize 13/07 & 34827 & 13264 & 91.7 & $55 \%$ & 9.1 & \pm 0.8 & $3.78 \pm 0.19$ & $12.0 \pm 0.1$ & nd & 94.9 & \pm 0.2 & 646 & \pm 30 \\
\hline & L2 & Decize $13 / 10$ & 38560 & 14083 & 42.7 & $25 \%$ & 1.8 & \pm 0.2 & $2.42 \pm 0.12$ & $13.4 \pm 0.1$ & $-13.00 \pm 0.02$ & 96.3 & \pm 0.2 & 525 & \pm 30 \\
\hline & L2 & Decize $14 / 03$ & 38571 & 14094 & 137.0 & $81 \%$ & 9.3 & \pm 0.8 & $2.20 \pm 0.11$ & $7.7 \pm 0.1$ & $-11.83 \pm 0.05$ & 98.6 & \pm 0.2 & 319 & \pm 30 \\
\hline & L3 & Saint Satur 13/04 & 33203 & 13114 & 447.0 & $150 \%$ & 15.0 & \pm 1.4 & $1.81 \pm 0.09$ & $5.6 \pm 0.1$ & nd & 91.5 & \pm 0.2 & 941 & \pm 30 \\
\hline & L3 & Saint Satur 13/07 & l & l & 165.0 & $55 \%$ & 3.8 & \pm 0.3 & $3.05 \pm 0.15$ & $8.7 \pm 0.1$ & nd & \multicolumn{2}{|l|}{ nd } & \multicolumn{2}{|l|}{ nd } \\
\hline & L3 & Saint Satur 13/10 & 38563 & 14086 & 104.0 & $35 \%$ & 2.2 & \pm 0.2 & $4.40 \pm 0.22$ & $19.0 \pm 0.2$ & $-11.01 \pm 0.03$ & 91.4 & \pm 0.2 & 948 & \pm 30 \\
\hline & L3 & Saint Satur 14/03 & 38758 & 14099 & 280.0 & $94 \%$ & 9.1 & \pm 0.8 & $4.13 \pm 0.21$ & $17.3 \pm 0.2$ & $-10.33 \pm 0.05$ & 90.6 & \pm 0.2 & 994 & \pm 30 \\
\hline & $\mathrm{L} 4$ & $\begin{array}{l}\text { Upstream } \\
\text { Belleville-sur-Loire } \\
04 / 09\end{array}$ & 2407 & l & 118.0 & $37 \%$ & 14.7 & \pm 1.3 & $3.55 \pm 0.18$ & $20.8 \pm 0.2$ & $-11.32 \pm 0.07$ & 91.5 & \pm 0.5 & 1238 & \pm 30 \\
\hline & $\mathrm{L} 4$ & $\begin{array}{l}\text { Upstream } \\
\text { Belleville-sur-Loire } \\
05 / 05\end{array}$ & 3960 & l & 377.0 & $117 \%$ & 17.2 & \pm 1.5 & $3.19 \pm 0.16$ & $22.5 \pm 0.2$ & nd & 91.0 & \pm 0.5 & 1259 & \pm 30 \\
\hline & $\mathrm{L} 4$ & $\begin{array}{l}\text { Upstream } \\
\text { Belleville-sur-Loire } \\
05 / 11\end{array}$ & 4884 & I & 131.0 & $41 \%$ & 4.5 & \pm 0.4 & $2.67 \pm 0.13$ & $19.1 \pm 0.2$ & nd & 93.0 & \pm 0.4 & 1084 & \pm 30 \\
\hline & L5 & $\begin{array}{l}\text { Bonny-sur-Loire } \\
05 / 05\end{array}$ & 3961 & l & 377.0 & $117 \%$ & 18.50 & \pm 1.7 & $3.17 \pm 0.16$ & $21.9 \pm 0.2$ & nd & 89.7 & $=0.7$ & 1375 & \pm 30 \\
\hline & L6 & Briare 13/04 & 33212 & 13123 & 443.0 & $138 \%$ & 4.5 & \pm 0.4 & $2.05 \pm 0.10$ & $8.9 \pm 0.1$ & $-9.62 \pm 0.08$ & 90.5 & \pm 0.3 & 1032 & \pm 30 \\
\hline & L6 & Briare 13/07 & 34837 & 13274 & 167.0 & $52 \%$ & 37.9 & \pm 3.4 & $3.11 \pm 0.16$ & $17.6 \pm 0.2$ & $-11.25 \pm 0.06$ & 89.9 & \pm 0.3 & 1082 & \pm 30 \\
\hline & L6 & Briare $13 / 10$ & 36814 & 14015 & 97.2 & $30 \%$ & 1.7 & \pm 0.2 & $3.49 \pm 0.17$ & $19.1 \pm 0.2$ & $-11.22 \pm 0.03$ & nd & & nd & \\
\hline & L6 & Briare 14/03 & 38794 & 14107 & 330 & $103 \%$ & 8.6 & \pm 0.8 & $3.33 \pm 0.17$ & $10.9 \pm 0.1$ & $-10.52 \pm 0.03$ & nd & & nd & \\
\hline \multirow[t]{5}{*}{ Allier } & A1 & Auzon 14/03 & 38567 & 14090 & 35.0 & $125 \%$ & 6.2 & \pm 0.6 & $0.61 \pm 0.03$ & $2.0 \pm 0.1$ & $-12.41 \pm 0.13$ & 100.9 & \pm 0.2 & 135 & \pm 30 \\
\hline & $\mathrm{A} 2$ & Le Veurdre 13/04 & 33202 & 13113 & 217.0 & $175 \%$ & 4.6 & \pm 0.4 & $1.56 \pm 0.08$ & $3.9 \pm 0.1$ & nd & 84.3 & \pm 0.3 & 1600 & \pm 30 \\
\hline & $\mathrm{A} 2$ & Le Veurdre $13 / 07$ & 34828 & 13265 & 62.7 & $51 \%$ & 6.1 & \pm 0.6 & $1.99 \pm 0.10$ & $17.0 \pm 0.2$ & $-9.47 \pm 0.02$ & 86.1 & \pm 0.3 & 1427 & \pm 30 \\
\hline & A2 & Le Veurdre $13 / 09$ & 38561 & 14084 & 42.0 & $34 \%$ & 9.8 & \pm 0.9 & $3.63 \pm 0.18$ & $16.1 \pm 0.2$ & $-9.32 \pm 0.03$ & 86.3 & \pm 0.2 & 1413 & \pm 30 \\
\hline & $\mathrm{A} 2$ & Le Veurdre $14 / 03$ & 38570 & 14093 & 149.0 & $120 \%$ & 10.8 & \pm 1.0 & $2.78 \pm 0.14$ & $12.2 \pm 0.1$ & $-7.57 \pm 0.10$ & 87.6 & \pm 0.3 & 1267 & \pm 30 \\
\hline \multirow[t]{2}{*}{ Cher } & $\mathrm{C} 1$ & Savonnières 13/04 & 33204 & 13115 & 127.0 & $161 \%$ & 3.8 & \pm 0.3 & $4.37 \pm 0.22$ & $21.5 \pm 0.2$ & $-16.00 \pm 1.00$ & 88.4 & \pm 0.2 & 1219 & \pm 30 \\
\hline & $\mathrm{C} 1$ & Savonnières 13/07 & 34830 & 13267 & 35.6 & $45 \%$ & 1.4 & \pm 0.1 & $5.26 \pm 0.26$ & $27.2 \pm 0.2$ & $-10.30 \pm 0.03$ & 85.5 & \pm 0.2 & 1481 & \pm 30 \\
\hline
\end{tabular}


Table 2 (Continued)

\begin{tabular}{|c|c|c|c|c|c|c|c|c|c|c|c|c|c|}
\hline Rivers & $\mathrm{Nr}$ & $\begin{array}{l}\text { Sampling location } \\
(\mathrm{y} / \mathrm{mm})\end{array}$ & $\begin{array}{l}\text { Lab nr } \\
\text { SacA- }\end{array}$ & $\begin{array}{l}\text { Lab nr } \\
\text { GifA- }\end{array}$ & $\begin{array}{l}\text { Discharge* } \\
\left(\mathrm{m}^{3} / \mathrm{s}\right)\end{array}$ & $\begin{array}{l}\text { Percentage of } \\
\text { mean discharge }\end{array}$ & $\begin{array}{l}\text { Chl-a } \\
(\mu \mathrm{g} / \mathrm{L}) \\
\end{array}$ & $\begin{array}{l}\text { Alkalinity } \\
\text { (meq/L) }\end{array}$ & $\begin{array}{l}\mathrm{DIC} \\
(\mathrm{mgC} / \mathrm{L})\end{array}$ & $\begin{array}{l}\delta^{13} \mathrm{C}-\mathrm{DIC} \\
(\% \circ)\end{array}$ & $\begin{array}{l}F^{14} \mathrm{C}-\mathrm{I} \\
100 \\
\end{array}$ & $\mathrm{DIC} *$ & $\begin{array}{l}\text { Reservoir } \\
\text { age }\left({ }^{14} \mathrm{C} \text { yr }\right)\end{array}$ \\
\hline & $\mathrm{C} 1$ & Savonnières $13 / 10$ & 38562 & 14085 & 25.3 & $32 \%$ & $1.6 \pm 0.1$ & $5.41 \pm 0.27$ & $17.6 \pm 0.2$ & $-12.21 \pm 0.08$ & 87.4 & \pm 0.2 & $1309 \pm 30$ \\
\hline & $\mathrm{C} 1$ & Savonnières $14 / 03$ & 38569 & 14092 & 90.2 & $114 \%$ & $4.9 \pm 0.4$ & $6.87 \pm 0.34$ & $37.1 \pm 0.2$ & $-9.16 \pm 0.04$ & 88.3 & \pm 0.2 & $1208 \pm 30$ \\
\hline & $\mathrm{C} 1$ & Savonnières $05 / 11$ & 4894 & I & 16.5 & $21 \%$ & $0.5 \pm 0.1$ & $5.54 \pm 0.28$ & $41.3 \pm 0.2$ & $-11.70 \pm 0.10$ & 88.7 & \pm 0.5 & $1465 \pm 30$ \\
\hline Indre & $\mathrm{I} 1$ & Le Neman $05 / 11$ & 4892 & l & nd & nd & $0.4 \pm 0.01$ & $7.74 \pm 0.39$ & $56.6 \pm 0.2$ & $-10.90 \pm 0.09$ & 87.5 & \pm 0.4 & $1574 \pm 30$ \\
\hline \multirow[t]{15}{*}{ Vienne } & V1 & $\begin{array}{l}\text { Lussac les } \\
\text { chateaux 13/04 }\end{array}$ & 33208 & 13119 & 145.0 & $195 \%$ & $2.0 \pm 0.2$ & $0.99 \pm 0.05$ & $2.1 \pm 0.1$ & nd & 97.0 & \pm 0.3 & $473 \pm 30$ \\
\hline & V1 & $\begin{array}{l}\text { Lussac les } \\
\text { chateaux 13/07 }\end{array}$ & 34831 & 13268 & 32.7 & $44 \%$ & $1.6 \pm 0.1$ & $1.23 \pm 0.06$ & $4.3 \pm 0.1$ & nd & 94.7 & \pm 0.2 & $667 \pm 30$ \\
\hline & V1 & $\begin{array}{l}\text { Lussac les } \\
\text { chateaux 13/10 }\end{array}$ & 38564 & 14087 & 32.5 & $44 \%$ & $1.1 \pm 0.1$ & $1.31 \pm 0.07$ & $7.1 \pm 0.1$ & $-12.64 \pm 0.04$ & 100.9 & \pm 0.3 & $150 \pm 30$ \\
\hline & V1 & $\begin{array}{l}\text { Lussac les } \\
\text { chateaux 14/03 }\end{array}$ & 38763 & 14104 & 133.0 & $179 \%$ & $6.8 \pm 0.6$ & $0.85 \pm 0.04$ & $4.0 \pm 0.1$ & $-11.42 \pm 0.06$ & 100.1 & \pm 0.2 & $200 \pm 30$ \\
\hline & $\mathrm{V} 2$ & $\begin{array}{l}\text { Amont Civaux } \\
13 / 07\end{array}$ & 36811 & 13281 & 32.7 & $44 \%$ & $0.7 \pm 0.1$ & $1.45 \pm 0.07$ & $10.3 \pm 0.1$ & $-13.25 \pm 0.03$ & 94.2 & \pm 0.4 & $703 \pm 30$ \\
\hline & $\mathrm{V} 2$ & $\begin{array}{l}\text { Amont Civaux } \\
13 / 10\end{array}$ & 36809 & 14011 & 32.5 & $44 \%$ & $1.4 \pm 0.1$ & $1.50 \pm 0.08$ & $7.5 \pm 0.1$ & $-12.24 \pm 0.05$ & 94.4 & \pm 0.3 & $690 \pm 30$ \\
\hline & V5 & Chauvigny $13 / 04$ & 33211 & 13122 & 147.0 & $177 \%$ & $6.1 \pm 0.6$ & $1.29 \pm 0.06$ & $4.7 \pm 0.1$ & $-12.18 \pm 0.06$ & 87.4 & \pm 0.2 & $1307 \pm 30$ \\
\hline & V5 & Chauvigny $13 / 07$ & I & l & 38.6 & $47 \%$ & $1.3 \pm 0.1$ & $1.90 \pm 0.10$ & nd & nd & nd & & nd \\
\hline & V5 & Chauvigny $13 / 10$ & 38797 & 14110 & 29.4 & $35 \%$ & $0.9 \pm 0.1$ & $2.14 \pm 0.11$ & $9.0 \pm 0.1$ & $-11.57 \pm 0.03$ & nd & & nd \\
\hline & V5 & Chauvigny $14 / 03$ & 38764 & 14105 & 138 & $166 \%$ & $6.2 \pm 0.6$ & $1.07 \pm 0.05$ & $6.5 \pm 0.1$ & $-11.48 \pm 0.05$ & nd & & nd \\
\hline & V7 & $\begin{array}{l}\text { Candes saint } \\
\text { Martin 05/11 }\end{array}$ & 4895 & l & nd & nd & $0.6 \pm 0.1$ & $4.39 \pm 0.22$ & $32.3 \pm 0.3$ & $-10.45 \pm 0.09$ & 80.5 & \pm 0.4 & $2244 \pm 30$ \\
\hline & V7 & $\begin{array}{l}\text { Candes saint } \\
\text { Martin 13/04 }\end{array}$ & 33205 & 13116 & 279.0 & $171 \%$ & $8.0 \pm 0.7$ & $2.53 \pm 0.13$ & $16.1 \pm 0.2$ & nd & 89.7 & \pm 0.2 & $1101 \pm 30$ \\
\hline & V7 & $\begin{array}{l}\text { Candes saint } \\
\text { Martin 13/07 }\end{array}$ & 38804 & 13282 & 96.9 & $59 \%$ & $8.0 \pm 0.7$ & $4.53 \pm 0.23$ & $19.4 \pm 0.2$ & $-11.42 \pm 0.03 r$ & nd & & nd \\
\hline & V7 & $\begin{array}{l}\text { Candes saint } \\
\text { Martin 13/10 }\end{array}$ & 38808 & 14117 & 81.1 & $50 \%$ & $1.3 \pm 0.1$ & $5.19 \pm 0.26$ & $19.3 \pm 0.2$ & $-11.78 \pm 0.03$ & nd & & nd \\
\hline & V7 & $\begin{array}{l}\text { Candes saint } \\
\text { Martin 14/03 }\end{array}$ & 38762 & 14103 & 328 & $201 \%$ & $4.9 \pm 0.4$ & $3.05 \pm 0.15$ & $14.7 \pm 0.1$ & $-11.42 \pm 0.06 r$ & nd & & nd \\
\hline \multirow[t]{2}{*}{ Mayenne } & Ma1 & Changé 14/03 & 38761 & 14102 & 34.3 & $116 \%$ & $15.1 \pm 1.2$ & $1.06 \pm 0.05$ & $5.4 \pm 0.1$ & $-11.16 \pm 0.03$ & 85.2 & \pm 0.2 & $1496 \pm 30$ \\
\hline & Ma2 & $\begin{array}{l}\text { Montreuil-Juigné } \\
13 / 04\end{array}$ & 33207 & 13118 & 158.0 & $417 \%$ & $32.7 \pm 2.9$ & $1.90 \pm 0.10$ & $7.7 \pm 0.1$ & $-13.61 \pm 0.06$ & 96.7 & \pm 0.3 & $492 \pm 30$ \\
\hline
\end{tabular}




\begin{tabular}{|c|c|c|c|c|c|c|c|c|c|c|c|c|c|}
\hline & Ma2 & $\begin{array}{l}\text { Montreuil-Juigné } \\
13 / 07\end{array}$ & 34834 & 13271 & 9.1 & $24 \%$ & $11.7 \pm 1.1$ & $3.50 \pm 0.17 \quad 8.5 \pm 0.1$ & nd & 97.7 & \pm 0.2 & 412 & \pm 30 \\
\hline & Ma2 & $\begin{array}{l}\text { Montreuil-Juigné } \\
13 / 10\end{array}$ & 36812 & 14013 & 6.5 & $17 \%$ & $53.4 \pm 4.8$ & $2.62 \pm 0.1316 .4 \pm 0.2$ & $-10.70 \pm 0.02$ & 100.6 & \pm 0.3 & 180 & \pm 30 \\
\hline & Ma2 & $\begin{array}{l}\text { Montreuil-Juigné } \\
14 / 03\end{array}$ & 38759 & 14100 & 42.9 & $113 \%$ & $44.7 \pm 4.0$ & $1.70 \pm 0.09 \quad 8.2 \pm 0.1$ & $-10.22 \pm 0.01$ & 99.0 & \pm 0.2 & 285 & \pm 30 \\
\hline Sarthe & S1 & Le Mans $14 / 03$ & 38568 & 14091 & 37.5 & $189 \%$ & $6.7 \pm 0.6$ & $5.89 \pm 0.2926 .2 \pm 0.3$ & $-11.04 \pm 0.04$ & 93.6 & \pm 0.3 & 740 & \pm 30 \\
\hline \multirow[t]{5}{*}{ Loir } & Lo1 & Bonneval 14/03 & 38565 & 14088 & 1.8 & $65 \%$ & $119.7 \pm 10.8$ & $4.63 \pm 0.2320 .3 \pm 0.2$ & $-8.74 \pm 0.03$ & 77.5 & \pm 0.2 & 2251 & \pm 30 \\
\hline & Lo2 & Briollay 13/04 & 33206 & 13117 & 130.0 & $463 \%$ & $54.8 \pm 4.9$ & $6.30 \pm 0.3233 .5 \pm 0.3$ & $-10.26 \pm 0.06$ & 82.0 & \pm 0.2 & 1823 & \pm 30 \\
\hline & Lo2 & Briollay 13/07 & 34835 & 13272 & 16.4 & $58 \%$ & $3.0 \pm 0.3$ & $7.54 \pm 0.3853 .4 \pm 0.5$ & nd & 82.0 & \pm 0.3 & 1817 & \pm 30 \\
\hline & Lo2 & Briollay $13 / 10$ & 36813 & 14014 & 22.5 & $80 \%$ & $1.3 \pm 0.1$ & $7.46 \pm 0.3745 .5 \pm 0.5$ & $-11.92 \pm 0.04$ & 79.8 & \pm 0.6 & 2041 & \pm 30 \\
\hline & Lo2 & Briollay $14 / 03$ & 38757 & 14098 & 33.2 & $118 \%$ & $152.8 \pm 13.8$ & $6.62 \pm 0.3335 .6 \pm 0.4$ & $-9.57 \pm 0.04$ & 84.3 & \pm 0.2 & 1580 & \pm 30 \\
\hline \multirow[t]{4}{*}{ Maine } & M1 & $\begin{array}{l}\text { Bouchemaine } \\
13 / 04\end{array}$ & 33209 & 13120 & nd & nd & $51.4 \pm 4.6$ & $3.70 \pm 0.1815 .9 \pm 0.2$ & $-10.49 \pm 0.08$ & 91.0 & \pm 0.3 & 987 & \pm 30 \\
\hline & M1 & $\begin{array}{l}\text { Bouchemaine } \\
13 / 07\end{array}$ & 34833 & 13270 & nd & nd & $11.0 \pm 1.0$ & $3.95 \pm 0.2035 .4 \pm 0.4$ & $-12.36 \pm 0.02$ & 86.0 & \pm 0.2 & 1440 & \pm 30 \\
\hline & M1 & $\begin{array}{l}\text { Bouchemaine } \\
13 / 10\end{array}$ & 36810 & 14012 & nd & nd & $6.4 \pm 0.6$ & $6.62 \pm 0.3339 .6 \pm 0.4$ & $-12.28 \pm 0.10$ & 84.7 & \pm 0.3 & 1562 & \pm 30 \\
\hline & M1 & $\begin{array}{l}\text { Bouchemaine } \\
14 / 03\end{array}$ & 38760 & 14101 & nd & nd & $48.0 \pm 4.3$ & $4.92 \pm 0.2525 .9 \pm 0.3$ & $-11.25 \pm 0.04$ & 89.0 & \pm 0.2 & 1140 & \pm 30 \\
\hline
\end{tabular}


The lowest DIC concentrations and alkalinities were observed upstream of the other rivers (except the Mayenne River because of a carbonate inclusion upstream) due to their localization in the crystalline area (Areas 1 and 3).

DIC $\delta^{13} \mathrm{C}$

These first data of DIC $\delta^{13} \mathrm{C}$ in the Loire Basin present high temporal and spatial variations ranging from $-7.66 \%$ o to $-13.61 \%$ with one low value of $-16 \pm 1 \%$ in Savonnières $(\mathrm{C} 1)$ in April 2013 and the highest DIC $\delta^{13} \mathrm{C}$ value of $-7.57 \%$ at Le Veurdre (A2) in March 2014. This variability is wide no matter the geological substrate. However, our DIC $\delta^{13} \mathrm{C}$ values are consistent with the results of studies conducted on other French rivers such as the study by Buhl et al. (1991) on the Rhine $\left(-10.7 \% \circ<\right.$ DIC $\delta^{13} \mathrm{C}<-4.4 \%$ ), the study by Aucour et al. (1999) on the Rhône River $\left(-11.3 \% \circ<\right.$ DIC $\delta^{13} \mathrm{C}<-4.1 \%$ ), and the study by Amiotte-Suchet et al. (1999) on the Strengbach River $\left(-24.4 \%<<\right.$ DIC $\delta^{13} \mathrm{C}<-9.3 \%$ ). Our seasonal variation analyses of DIC $\delta^{13} \mathrm{C}$ indicate an amplitude variation of about $5 \%$ with a trend toward lower values in late summer. This trend is consistent with a higher contribution in late summer from the decomposition of soil organic matter compared to a higher contribution of carbonate weath-ering during the spring. As the carbon isotopic composition of DIC in freshwater is controlled by different processes such as carbon exchanges with the atmosphere, $\mathrm{CO}_{2}$ degassing in volcanic areas, dissolution of carbonate from the geological substrate, decay of organic matter in continental soils or in phytoplanktonic production, no direct relation could be established. Other proxies and parameters are needed to discriminate between these processes.

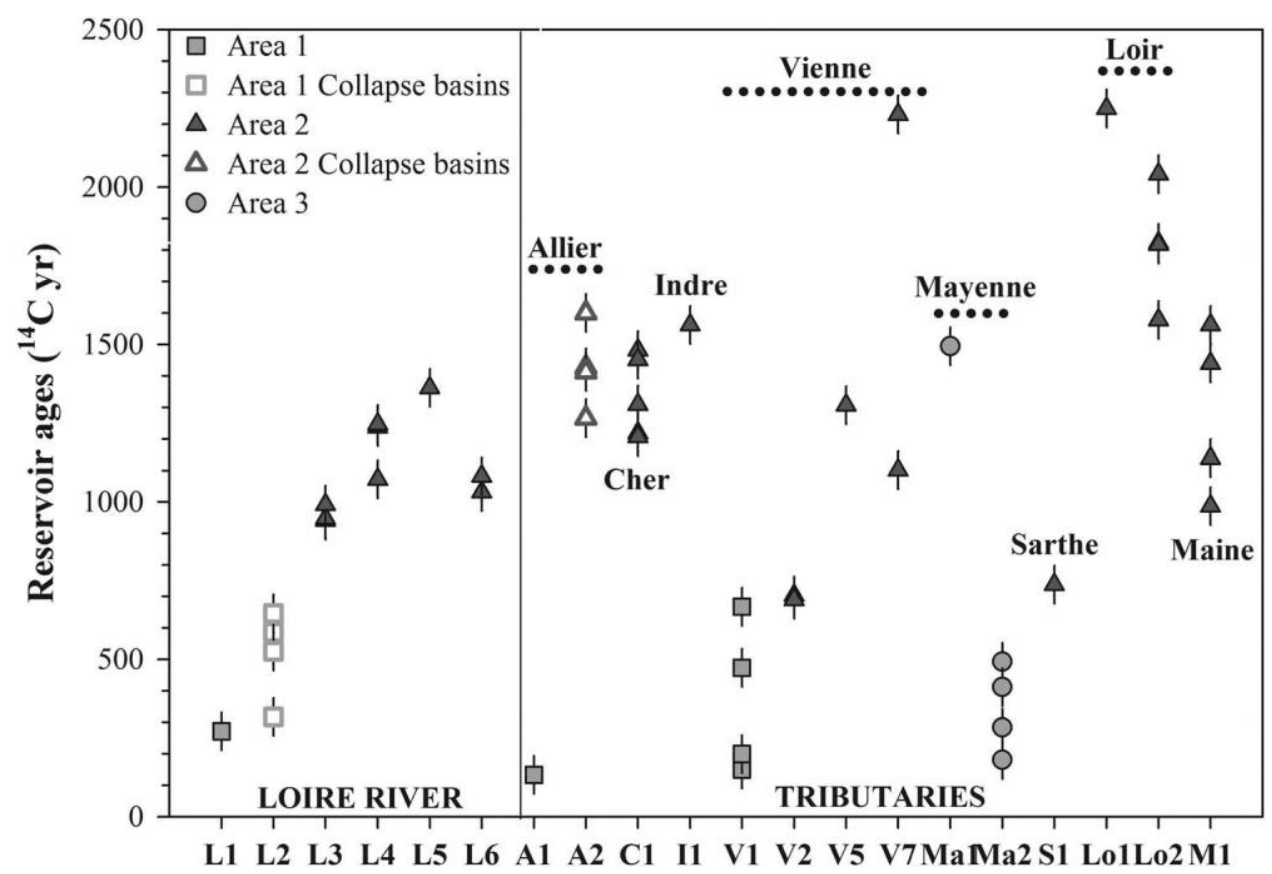

Figure 2 Reservoir ages evolution during the four campaigns from upstream to downstream for the Loire (L), Allier (A), Cher (C), Indre (I), Vienne (V), Mayenne (Ma), Sarthe (S), Loir (Lo) and Maine (M) Rivers. The orange markers correspond to sites in Areas 1 and 3, the blue markers to the sites in Area 2 (online color version). The error is expressed at $2 \sigma$. 


\section{Reservoir Ages}

The reservoir age values were highly variable across the Loire Basin, ranging between 135 and $2251{ }^{14} \mathrm{C}$ yr. The FRE did not exceed $667{ }^{14} \mathrm{C}$ yr in Areas 1 and 3, except at Ma1 $\left(1496{ }^{14} \mathrm{C}\right.$ yr $)$. In Area 2, higher FRE ( $>690{ }^{14} \mathrm{C}$ yr) was recorded (Figure 2), ranging from 690 and $2251{ }^{14} \mathrm{C} \mathrm{yr}$, except upstream of the Vienne (V1 and V2).

\section{Spatial Variability}

The DIC concentrations, alkalinity, and stable carbon isotope ratios combined with the geological substrate can be used to explain the difference in FRE values between the sedimentary Area 2, mainly composed of limestone containing old calcium carbonate, and the two different crystalline Areas 1 and 3 as well as the exceptional data.

Higher FRE offsets in Area 2 are consistent both with high alkalinity values (and DIC content) as indicated by the good correlation $(r=0.61 ; n=49 ; \mathrm{p}<0.05)$ obtained between FRE and these parameters, shown in Figure 3.

Limestone dissolution seems to be the main process that controls DIC in the Area 2 rivers. The fact that the highest reservoir age was recorded in the Loire River corroborates the assertion that limestone dissolution is the main process controlling DIC in these waters. Indeed, the Loire River crosses the limestone area of the Beauce Plateau where agricultural practices promote extensive drainage as shown by the high values of chl-a concentrations observed related to the heavy runoff of fertilizers (Barnes and Raymond 2009). This drainage also results in high carbonate dissolution.

High FRE offsets, well correlated with alkalinity and DIC concentration, were also observed in crystalline areas, e.g. at L2, Ma1, S1, V1, and V2 (Figure 2). At these five sites, the results can be explained by more precise geological information. At L2, the Loire crosses the Forez and Roanne basins. The collapse basins are rich in carbonates even if the basement is plutonic (Derruau 1949; Boineau and Maisonneuve 1971; Cochet and Belkessa 1972; Landry 1988; Négrel et al. 2003; Rivé et al. 2013). The high FRE offsets observed (mean of $519{ }^{14} \mathrm{C}$ yr) could be the result of two processes: the percolation of groundwater through the marl faulted

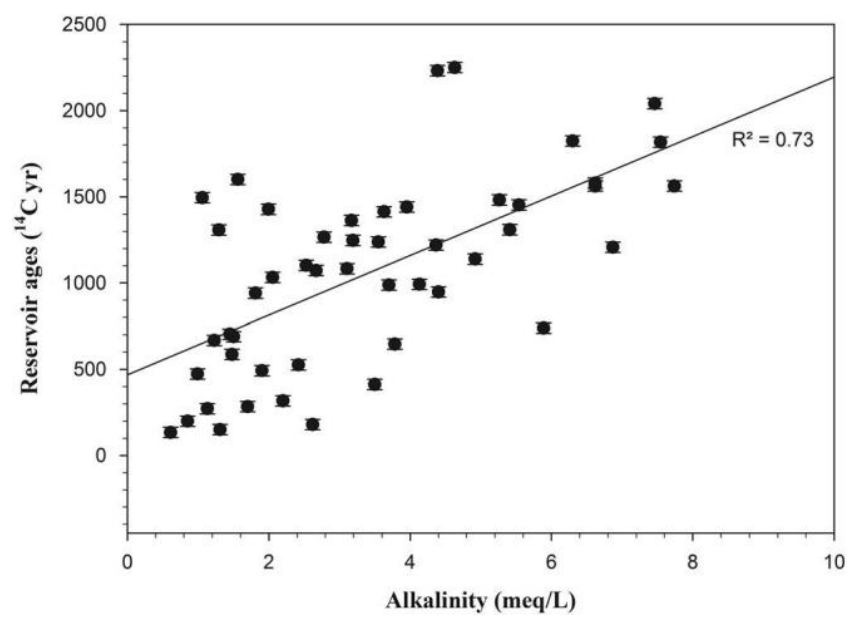

Figure 3 Reservoir ages and alkalinity correlation 
substrate or volcanic $\mathrm{CO}_{2}$ degassing well known in this region of the Massif Central (Anonymous 1997), or both. At Le Veurdre (A2) on the Allier River located also in the collapse basins, the DIC $\delta^{13} \mathrm{C}$ values, from -7.5 to $-9.5 \%$ (Table 2 ), are the least depleted values recorded in the Loire Basin and its tributaries, suggesting a potentially higher contribution of volcanic $\mathrm{CO}_{2}$ with DIC $\delta^{13} \mathrm{C}$ values around $-6 \%$ (Assayag 2006). At Changé (Ma1) in Area 3, a high FRE was observed due to the presence of carbonates that permeate the sedimentary matrix and are dissolved in the outcrop (Aertgeerts et al. 2011a). At S1, the FRE was lower $\left(740{ }^{14} \mathrm{C}\right.$ yr) than at other sampling sites in Area 2 because the S1 station is situated at the exit of a schist area poor in carbonates (Aertgeerts et al. 2011b). Finally, upstream of the Vienne (V1 and V2), the Vienne River starts running through Area 2 at V1, explaining the still young reservoir age at V1 and the increase in age along the Vienne River. Spatial changes in FRE values depend mainly on the geological substrate and agricultural practices. Indeed, we observed a systematic increase in FRE values between upstream and downstream of the sedimentary area due to the increase in the dissolution of carbonate and silicate along the river. This increase can be very pronounced within a few kilometers, as on the Vienne River, where the FRE values increased from $200 \mathrm{yr}$ at V1 to more than $1300 \mathrm{yr}$ (V5) in only $20 \mathrm{~km}$ (SAGE 2006).

This rapid increase in FRE values may not be related to the dissolution of substrate alone and cannot also be attributed to organic inputs. Fast changes are often due to a mixing of different waters with different ${ }^{14} \mathrm{C}$ signatures. Currently, the rapid changes in river characteristics are related to the arrival of new sources of water with different properties. These changes in the characteristics and ${ }^{14} \mathrm{C}$ signature of water were observed on the Maine River, which is at the confluence of the Mayenne, Sarthe, and Loir rivers. The waters of these three tributaries have different signatures (FRE, DIC content, and alkalinity values), and the Maine River values vary between these three sources depending on their relative contributions. If we apply a simple mass balance equation of two source water masses for the Vienne River, it seems that between site V1 and V5, the arrival of ${ }^{14} \mathrm{C}$-depleted underground water can explain this rapid aging of FRE. Further investigations are necessary to validate this hypothesis, however.

\section{Temporal Variability}

Temporal variability over $1 \mathrm{yr}$ and four campaigns was obtained at each sampling point, except in the middle course of the Loire River (L3 to L6). The observed variability is high, ranging from $257 \mathrm{yr}$ at Savonnières upstream of the Cher River $(\mathrm{C} 1)$ to $575 \mathrm{yr}$ at Bouchemaine on the Maine River (M1), except on the middle Loire (L3, L4, L6). In this area, the temporal variation of the FRE ranges from 50 to $165 \mathrm{yr}$, but is not statistically significant, as indicated by the chi-squared test.

Contrary to expectations, the reservoir age and alkalinity data (Table 2) did not show any correlation with the flow of rivers expressed as a percentage of mean discharge. These data showed no evidence of a decrease in alkalinity or FRE resulting from dilution by meteoritic water during flood periods. This finding is valid for sites both in crystalline and in limestone sedimentary areas.

One explanation is the fact that the meteorological data in the days preceding the sampling are not known and we do not know in which phase of the flood the sampling was done. It is also possible that while runoff directly feeds the river during floods in the crystalline area, it is not the same for the rivers in a limestone substrate where rainwater can pass through the water table and be recharged in ${ }^{14} \mathrm{C}$-dead bicarbonate. Nevertheless, our data for the crystalline area tend to decrease with increasing percentage of the average flow. 


\section{CONCLUSION}

The FRE in the Loire River Basin shows a wide range of variation between 135 to $2251 \mathrm{yr}$. The FRE is mainly influenced by the geological substrate and especially by the dissolution of old carbonate. Consequently, it is positively correlated with the alkalinity and mineral carbon contents of waters. Seasonal variations in reservoir ages were observed, but no direct link with river flows was noticed. This finding is valid for sites both in crystalline and in limestone sedimentary areas. Due to the large spatial and temporal variability of DIC reservoir ages in the Loire Basin, it appears difficult to use this parameter to establish a wide-ranging baseline of reservoir age. According to Keaveney and Reimer (2012) and Fernandes et al. (2014), biolo-gical or particulate organic carbon samples that integrate the DIC variations would be a better approach to propose ${ }^{14} \mathrm{C}$ FRE corrections for the establishment of reliable chronologies.

\section{ACKNOWLEDGMENTS}

This study was supported by the National Association of Research and Technology (ANRT), EDF $\mathrm{R} \& D$, and the CEA. Thanks are due to Christine Hatte for the $\delta^{13} \mathrm{C}$ analysis; Bernard Berthier, Emmanuelle Delque-Količ and the team of the ARTEMIS Saclay AMS facilities for the ${ }^{14} \mathrm{C}$ measurements; Sabrina Bichon and Bruno Deflandre of the Laboratory EPOC, Bordeaux for chlorophyll pigment measurements; and Christophe Rabouille and Bruno Bombled for the alkalinity instrumentation. Comments and suggestions by the Radiocarbon referees and editors significantly improved the manuscript. This is LSCE contribution $n^{\circ} 5696$.

\section{REFERENCES}

Abonyi A, Leitão M, Lançon AM, Padisák J. 2012. Phytoplankton functional groups as indicators of human impacts along the River Loire (France). Hydrobiologia 698(1):233-49.

Abonyi A, Leitão M, Stankovic I, Borics G, Varbiro G, Padisák J. 2014. A large river (River Loire, France) survey to compare phytoplankton functional approaches: Do they display river zones in similar ways? Ecological Indicators 46:11-22.

Aertgeerts G, Béchennec F, Conil P, Régnault S, Mary G, Papillard M, Pivette B, Redois F, Viaud JM. 2011a. Identification et diagnostic du patrimoine géologique en Pays de la Loire. Inven-taire des sites géologiques remarquables. Annexe 2 - tome 3 - Fiches argumentaires de Mayenne. 212 p.

Aertgeerts G, Béchennec F, Conil P, Régnault S, Mary G, Papillard M, Pivette B, Redois F, Viaud JM. 2011b. Identification et diagnostic du patrimoine géologique en pays de la Loire. Inventaire des sites géologiques remarquables. Rapport Final. Annexe 2 - tome 4: Fiches argumentaires de Sarthe. 195 p.

Aleya L, Desmolles F, Michard M, Bonnet M-P, DevauxJ. 1994. The deterministic factors of the Microcystis aeruginosa blooms over a biyearly survey in the hypereutrophic reservoir of Villerest (Roanne, France). Archiv fuer Hydrobiologie 120:489-515.

Amiotte-Suchet P, Aubert D, Probst JL, GauthierLafaye F, Probst A, Andreux F, Viville D. 1999. $\delta^{13} \mathrm{C}$ pattern of dissolved inorganic carbon in a small granitic catchment: the Strengbach case study (Vosges mountains, France). Chemical

Geology 159(1-4):129-45.

Anonymous. 1997. Les eaux minérales et le gaz carbonique. Note Technique DNEMT $\mathrm{N}^{\circ} 10$ DNEMT \& BRGM. Paris: Ministére de l'Economie, des Finances et de l'Industrie. 23p.

Ascough PL, Cook GT, Church MJ, Dunbar E, Einarsson A, McGovern TH, Gugmore AJ, Perdikaris S, Hastie H, Fridrikss on A, Gestsdottir H. 2010. Temporal and spatial variations in freshwater ${ }^{14} \mathrm{C}$ reservoir effects: Lake Mývatn, northern Iceland. Radiocarbon 52(2-3): 1098-112.

Assayag N. 2006. Traçage isotopique des sources, puits et de la réactivité du $\mathrm{CO}_{2}$ dans les réservoirs géologiques [PhD thesis]. Institut Physique du Globe de Paris. 195 p.

Aucour AM, Sheppard SMF, Guyomar O, Wattelet J. 1999. Use of ${ }^{13} \mathrm{C}$ to trace origin and cycling of inorganic carbon in the Rhône river system. Chemical Geology 159:87-105.

Barnes RT, Raymond P. 2009. The contribution of agricultural and urban activities to inorganic carbon fluxes within temperate watersheds. Chemical Geology 266:327-36.

Boineau R, Maisonneuve J. 1971. Les sources minerales du Massif Central français et leur cadre géologique. $17 \mathrm{p}$.

Bonsall C, Cook GT, Hedges REM, Higham TFG, Pickard C, Radovanovic I. 2004. Radiocarbon and stable isotope evidence of dietary change from the Mesolithic to the Middle Ages in the Iron 
Gates: new results from Lepenski Vir. Radiocarbon 46(1):293-300.

Boudin M, Van Strydonck M, Crombé P. 2009. Radiocarbon dating of pottery food crusts: reservoir effect or not? The case of the Swifterbant pottery from Doel "Deurganckdok" (Belgium). In Crombé P, Van Strydonck M, Sergant J, Boudin M, Bats M, editors. Chronology and Evolution within the Mesolithic of North-West Europe: Proceedings of an International Meeting. Newcastle Upon Tyne: Cambridge Scholars Publishing. p 727-45.

Broecker WS, Walton A. 1959. The geochemistry of ${ }^{14} \mathrm{C}$ in freshwater systems. Geochimica et Cosmochimica Acta 16:15-38.

Buhl D, Neuser RD, Richter DK, Riedel D, Roberts B, Strauss H, Veizer J. 1991. Nature and nurture: environmental isotope story of the river Rhine. Naturwis senschaften 78:337-46.

Cochet A, Belkessa R. 1972. Plaine alluviale du val d'Allier au nord de Moulins. Etude hydrogéologique préliminaire. $21 \mathrm{p}$.

Cook GT, Bonsall C, Hedges REM, McSweeney K, Boroneant V, Pettitt PB. 2001. A freshwater dietderived ${ }^{14} \mathrm{C}$ reservoir effect at the Stone Age sites in the Iron Gates Gorge. Radiocarbon 43(2A): 453-60.

Cottereau E, Arnold M, Moreau C, Baqué D, Bavay D, Caffy I, Comby C, Dumoulin J-P, Hain S, Perron M, Salomon J, Setti V. 2007. Artemis, the new ${ }^{14} \mathrm{C}$ AMS at LMC14 in Saclay, France. Radiocarbon 49(2):291-9.

Couderc J-M. 1968. Les phénomènes d'hydrologie karstique en Touraine. Norois 58:227-51.

Deevey ESJ, Gross MS, Hutchinson GE, Kraybill HL. 1954. The natural $\mathrm{C}^{14}$ contents of materials from hard-water lakes. Geology 40:285-8.

Derruau M. 1949. La formation du relief de la Grande Limagne (Première partie). Revue de Géographie Alpine 37(4):599-670.

Fernandes R, Rinne C, Nadeau M-J, Grootes P. 2014. Towards the use of radiocarbon as a dietary proxy: establishing a first wide-ranging radiocarbon reservoir effects baseline for Germany. Environmental Archaeology. DOI:10. 1179/1749631414Y.0000000034.

Figueres G, Martin JM, Meybeck M, Seyler P. 1985. A comparative study of mercury contamination in the Tagus Estuary (Portugal) and major French Estuaries (Gironde, Loire, Rhône). Estuarine, Coastal and Shelf Science 20:183-203.

Fontes JC, Gasse F. 1991. PALHYDAF (Palaeohydrology in Africa) program: objectives, methods, major results. Palaeogeography, Palaeoclimatology, Palaeoecology 84:191-215.

Fontugne M, Abril G, Bacon A, Baumier D, Commarieu MV, Connan O, Etcheber H, Germain P, Hébert D, Jean-Baptiste P, Lozay C, Maro D, Olivier A, Paterne M, Podevin V, Poirier D, Rozet M, Tenailleau L. 2007. Transferts de carbone 14 et tritium entre la Loire et l'atmosphère. Rapport final LORA: Contrat de partenariat EDF/CNRS. 118 p.

Fontugne M, Guichard F, Bentaleb I, Strechie C, Lericolais G. 2009. Variations in ${ }^{14} \mathrm{C}$ reservoir ages of Black Sea waters and sedimentary organic carbon during anoxic periods: influence of photosynthetic versus chemoautotrophic production. Radiocarbon 51(3):969-76.

Garnier J, Servais P, Billen G, Akopian M, Brion N. 2001. Lower Seine river and estuary (France) carbon and oxygen budgets during low flow. Estuaries 24(6B):964-76.

Grosbois C. 1998. Géochimie des eaux de la Loire: contributions naturelles et anthropiques et quantification de l'érosion $[\mathrm{PhD}$ thesis]. Université François Rabelais. 232 p.

Hall BL, Henderson GM. 2001. Use of uraniumthorium dating to determine past ${ }^{14} \mathrm{C}$ reservoir effects in lakes: examples from Antarctica. Earth and Planetary Science Letters 193:565-77.

Hart JP, Lovis WA, Urquhart GR, Reber EA. 2013. Modeling freshwater reservoir offsets on radiocarbon-dated charred cooking residues. American Antiquity 78(3):536-52.

Higham T, Warren R, Belinskij A, Härke H, Wood R. 2010. Radiocarbon dating, stable isotope analysis, and diet-derived offsets in ${ }^{14} \mathrm{C}$ ages from the KlinYar site, Russian North Caucasus. Radio-carbon 52(2-3):653-70.

Hollund HI, Higham T, Belinskij A, Korenevskij S. 2010. Investigation of palaeodiet in the North Caucasus (South Russia) Bronze Age using stable isotope analysis and AMS dating of human and animal bones. Journal of Archaeological Science 37:2971-83.

Jugnia L, Debroas D, Romagoux J, Dévaux J. 2004. Initial results of remediation activities to restore hypereutrophic Villerest Reservoir (Roanne, France), Lakes and Reservoirs. Research and Management 9:109-17.

Keaveney E, Reimer P. 2012. Understanding the varaibility in freshwater radiocarbon reservoir offsets: a cautionary tale. Journal of Archaelogical Science 39(5):1306-16.

Landry J. 1988. Barrage du Veurdre sur l'Allier. Reconnaissances géologiques, géotechniques et hydrogéologiques préliminaires. Rapport de synthèse. $7 \mathrm{p}$.

Leboucher V, Orr J, Jean-Baptiste P, Arnold M, Monfray P, Tisnerat-Laborde N, Poisson A, Duplessy J-C. 1999. Oceanic radiocarbon between Antarctica and South Africa along WOCE Section 16 at $30^{\circ}$ E. Radiocarbon 41(1): 51-73.

Levin I, Kromer B, Hammer S. 2013. Atmospheric ${ }^{14} \mathrm{CO} 2$ trend in Western European background air from 2000 to 2012. Tellus B 65:1-7.

Mansy J-L, Guennoc P, Robaszynski F, Amédro F, Auffret J-P, Vidier J-P, Lamarche J, Lefevre D, Somme J, Brice D, Mistiaen B, Prud'Homme A, Rohart J-C, Vachard D. 2008. Notice explicative 
de la carte géologique de la France (1/50000). Feuille Marquise (2nd édition). BRGM. 213 p.

Marang L, Siclet F, Luck M, Maro D, Tenailleau L, Jean-Baptiste P, Fourré E, Fontugne M. 2011. Modelling tritium flux from water to atmosphere: application to the Loire River. Journal of Environmental Radioactivity 102:244-51.

Minaudo C, Moatar F, Meybeck M, Curie F, Gassama N, Leitao M. 2013. Loire River eutro-phication mitigation (1981-2011) measured by seasonal nutrients and algal biomass. IAHS Publication Symposia H:1-9.

Minaudo C, Meybeck M, Moatar F, Gassama N, Curie F. 2015. Eutrophication mitigation in rivers: 30 years of trends and seasonality changes in biogeochemistry of the Loire River (1980-2012). Biogeosciences 12:2549-63.

Négrel P, Petelet-Giraud E, Barbier J, Gautier E. 2003. Surface water-groundwater interactions in an alluvial plain: chemical and isotopic systema-tics. Journal of Hydrology 277(3-4):248-67.

Neveux J, Lantoine F. 1993. Spectrofluorometric assay of chlorophylls and phaeopigments using the least squares approximation technique. Deep-SeA Research I 40(9):1747-65.

Oana S, Deevey ES. 1960. Carbon 13 in lake waters, and its possible bearing on paleolimnology. American Journal of Science 258A:253-72.

Olsen J, Heinemeier J, Lübke H, Lüth F, Terberger T. 2010. Dietary habits and freshwater reservoir effects in bones from a Neolithic NE German cemetery. Radiocarbon 52(2-3):635-44.

Philippsen B. 2012. Variability of freshwater reservoir effects. Implications for radiocarbon dating of prehistoric pottery and organisms from estuarine environments $[\mathrm{PhD}$ thesis]. Aarhus: Aarhus University. 237 p.

Philippsen B. 2013. The freshwater reservoir effect in radiocarbon dating. Heritage Science 1:24.

Philippsen B, Heinemeier J. 2013. Freshwater reservoir effect variability in northern Germany. Radiocarbon 55(2-3): 1085-101.

Philippsen B, Kjeldsen H, Hartz S, Paulsen H, Clausen I, Heinemeier J. 2010. The hardwater effect in AMS ${ }^{14} \mathrm{C}$ dating of food crusts on pottery. Nuclear Instruments and Methods in Physics Research B 268(7-8):995-8.
Reimer PJ, Baillie MGL, Bard E, Bayliss A, Beck JW, Bertrand CJH, Blackwell PG, Buck CE, Burr GS, Cutler KB, Damon PE, Edwards RL, Fairbanks RG, Friedrich M, Guilderson TP, Hogg AG, Hughen KA, Kromer B, McCormac G, Manning S, Bronk Ramsey C, Reimer RW, Remmele S, Southon JR, Stuiver M, Talamo S, Taylor FW, van der Plicht J, Weyhenmeyer CE. 2004. IntCal04 terrestrial radiocarbon age calibration, 0-26 cal kyr BP. Radiocarbon 46(3):1029-58.

Rivé K, Rad S, Assayag N. 2013. Carbon sources and water-rock interactions in the Allier River, France. Procedia Earth and Planetary Science 7:713-6.

SAGE. 2006. Forces et faiblesses. Approche cartographique du bassin de la Vienne. $81 \mathrm{p}$.

Sato T, Miyajima T, Ogawa H, Umezawa Y, Koike I. 2006. Temporal variability of stable carbon and nitrogen isotopic composition of size-fractionated particulate organic matter in the hypertrophic Su mid a River Estuary of Tokyo Bay, Japan. Estuarine, Coastal and Shelf Science 68(1-2):245-58.

Shishlina NI, van der Plicht J, Hedges REM, Zazovskaya EP, Sevastyanov VS, Chichagova OA. 2007. The catacomb cultures of the North-West Caspian Steppe: ${ }^{14} \mathrm{C}$ chronology, reservoir effect, and paleodiet. Radiocarbon 49(2):713-26.

Siclet F, Guesmia M, Ciffroy P, Reyss JL, Fontugne M, Lepetit G, Jean-Baptiste P, Drouadaine L. 2002. Radionuclides in the Loire River estuary (France): sources, transport and fate. Radioprotection 37(C1): 761-7.

Sorey ML, Evans WC, Kennedy BM, Farrar CD, Hainsworth LJ, Hausback B. 1998. Carbon dioxide and helium emissions from a reservoir of magmatic gas beneath Mammoth Mountain, California. Journal of Geophysical Research 103(B7):15,30323.

Stuiver M, Polach HA. 1977. Discussion: reporting of ${ }^{14} \mathrm{C}$ data. Radiocarbon 19(3):355-63.

Sveinbjörnsdóttir ÁE, Heinemeier J, Arnorsson S. 1995. Origin of ${ }^{14} \mathrm{C}$ in Icelandic groundwater. Radiocarbon 37(2):551-65.

Van Strydonck M, Ervynck A, Vandenbruaene M, Boudin M. 2009. Anthropology and ${ }^{14} \mathrm{C}$ analysis of skeletal remains from relic shrines: an unexpected source of information for Medieval archaeology. Radiocarbon 51(2):569-77. 